\title{
Analysis of the Hardin A Site (41GG69) Faunal Remains
}

\section{LeeAnna Schniebs}

Unknown

Follow this and additional works at: https://scholarworks.sfasu.edu/ita

Part of the American Material Culture Commons, Archaeological Anthropology Commons, Environmental Studies Commons, Other American Studies Commons, Other Arts and Humanities Commons, Other History of Art, Architecture, and Archaeology Commons, and the United States History Commons

Tell us how this article helped you.

This Article is brought to you for free and open access by the Center for Regional Heritage Research at SFA ScholarWorks. It has been accepted for inclusion in Index of Texas Archaeology: Open Access Gray Literature from the Lone Star State by an authorized editor of SFA ScholarWorks. For more information, please contact cdsscholarworks@sfasu.edu. 


\section{Analysis of the Hardin A Site (41GG69) Faunal Remains}

Creative Commons License

(c) (i) (8)

This work is licensed under a Creative Commons Attribution-NonCommercial 4.0 International License 


\title{
Analysis of the Hardin A Site (41GG69) Faunal Remains
}

\author{
LeeAnna Schniebs
}

\section{INTRODUCTION}

The excavation of the Hardin A site (41GG69), a late $14^{\text {th }}$ to early $15^{\text {th }}$ century A.D. period Caddo site in Gregg County, Texas (Boyd and Perttula 2001), yielded 495 faunal specimens. This sum includes all bone fragments, and pieces of antler and turtle shell. Total weight of the assemblage is 266.6 grams. Faunal material was recovered from 15 levels in a single $1 \times 2 \mathrm{~m}$ unit comprised of a midden deposit and feature fill. The remainder of the article discuss the methods employed in the faunal analysis, results of taxonomic identification and quantification, and the distribution of these remains.

\section{METHODOLOGY}

All prehistoric vertebrate remains were inventoried and weighed. Excel 5.0 for Windows was used to manipulate the generated data. An Ohaus digital scale, Model CT600-S, was used to record bone weight. I analyzed all the recovered fragments, using comparative collections on loan from or housed at the Institute of Applied Sciences, Zooarchaeology Lab, University of North Texas, Denton, Texas. Occasional supplements were required, using conventional osteological keys such as Olsen (1964), Gilbert (1980), and Schmid (1972). Identifications were made to the most specific category possible depending on the condition of the bone and available comparative material. Only positive identifications resulted in the assignment of elements to genus or species.

Standard zooarchaeological methods have been used. Both unidentifiable and identifiable pieces were analyzed in similar fashion. That is, the same attributes were recorded: taxon, element and portion of that element, anatomical location of the element, condition of the bone and any notes on age, taphonomy, burning or breakage patterns, and presence of modification if applicable. Provenience information was also recorded.

Quantification of the assemblage is summarized as minimum number of identified specimens per taxon (NISP) and as minimum number of individuals (MNI) for identified elements. MNI estimates were calculated according to the most frequently occurring element, based on symmetry and element portion (Munzel 1986). In some cases, complete long bones and proximal or distal ends were considered. In other cases, the presence of a single element constituted an MNI of one.

Those specimens regarded as unidentifiable (those coded to only class or order) have been consolidated into a few general categories. Elements of non-diagnostic skeletal value (ribs, vertebrae and long bone shafts; Olsen 1964), are coded in an indeterminate category by class and/or size range. For example, specimens counted as "small mammal" are from gopher or rabbit-size mammals, and "large mammal" refers to a deer-size mammal. "Indeterminate vertebrate" includes the bones uncertain of class, usually either bird or mammal. Recording these specimens in a size category enables the most precise level of observation as the specimen allows. In small samples, taking note of weight and the size categories of non-diagnostic elements broadens the function of the bone assemblage. However, percentages are calculated by number of bones (NISP) rather than weight. 


\section{RESULTS}

Taxonomic classes identified include fish, reptile, bird, and mammal (marsupialia, lagomorpha, rodentia, and artiodactyla). The faunal assemblage from the Hardin A site is dominated by unidentifiable large mammal remains. Various other small and medium animals are represented, although occurrences are less frequent. Only one of the faunal specimens is modified: slight cuts are noted on a large mammal rib fragment.

\section{Assemblage Composition}

\section{Class Osteichthyes}

Order Lepisosteiformes, Family Lepisosteidae: Gar (Lepisosteus sp.) is represented by two fragments. A vertebra was recovered from Level 3 in the midden deposit (20 to $30 \mathrm{~cm} \mathrm{bs}$ ), and a burned cranial element was found in Level 9 in Feature 1 fill (80 to $90 \mathrm{~cm}$ bs). Gars are cigar-shaped predatory fish with thick ganoid (diamond-shaped) scales and beak-like jaws with sharp pointed teeth. They are known to frequent large streams, rivers, and shallow, weedy lakes, where they spawn in spring. They can use atmospheric oxygen and may bask on the surface of the water (Collins 1959).

Order Cypriniformes, Family Catostomidae: Buffalo fish (Ictiobus sp.) is represented by one fragment. It was recovered from Level 7 in Feature 1 fill $(60$ to $70 \mathrm{~cm} \mathrm{bs})$. There are three species of this genus in this part of the Sabine River basin.

Preferring deep, clear, swift waters of large rivers, Buffalo fish in general are prolific and will often dominate a lake at the expense of other fish. They are deep-bodied and heavy headed fish, feeding on mollusks, crustaceans, insect larvae, and plants. They can weigh up to 30 pounds (Collins 1959).

Order indeterminate: Five fragments from unidentifiable medium-sized bony fish were recovered from Levels 6 through 9 (50 to $90 \mathrm{~cm} \mathrm{bs).} \mathrm{None} \mathrm{of} \mathrm{these} \mathrm{specimens} \mathrm{are} \mathrm{burned.}$

\section{Class Reptilia}

Order Testudinata, Family Kinosternidae: Musk/mud turtle (Kinosternidae) is represented by four burned shell fragments. Two pieces were recovered from Level 6 in the midden deposit (50 to $60 \mathrm{~cm} \mathrm{bs}$ ), and two pieces were recovered from Level 8 in Feature 1 fill $(70$ to $80 \mathrm{~cm} \mathrm{bs})$. There are two genera north of Mexico: Sternotherus, with four species of musk turtles, and Kinosternon, with five species of mud turtles. Currently, the mud turtle (K. subrubrum), the musk turtle (S. carinatus), and the stinkpot (S. odoratus) are found in the area.

These turtles all generally prefer slow-moving or shallow waters with soft bottoms and abundant vegetation. They all have two pairs of musk glands beneath the border of the carapace; the secretions are very offensive (Behler 1995).

Order Testudinata, Family Emydidae: Box turtle (Terrapene sp.) is represented by one burned shell fragment recovered from Level 1 in the midden deposit (0 to $10 \mathrm{~cm} \mathrm{bs).} \mathrm{Box} \mathrm{turtles,} \mathrm{which} \mathrm{are} \mathrm{strictly}$

North American, range widely over the eastern and central United States and into the Southwest, and they also occur in many parts of Mexico. These are dry-land turtles that close their shells tightly when danger threatens (Conant 1975).

Order Testudinata (family indeterminate): Thirty-four shell fragments from unidentifiable turtle were recovered from Levels 3 through 15. Quantities range from one to six. Thirty-two specimens are burned. 


\section{Class Aves}

Order Galliformes, Family Phasianidae: Turkey (Meleagris gallopavo) is represented by one specimen. This burned tarsometatarsus fragment was recovered from Level 5 in the midden deposit ( 40 to $50 \mathrm{~cm} \mathrm{bs}$ ). Turkey occurs as wild fowl in open woodland environments (Robbins 1983), but currently it does not occupy the immediate area. Its range includes areas just to the east. Although it is a good flier, the turkey prefers to run from predators, and roosts in trees (Collins 1959). The fragment is probably the remains of a game bird, as the Caddos were known to hunt turkey (Newcomb 1993).

Order indeterminate: Unidentifiable large bird is represented by one ulna fragment recovered from Level 9 in Feature 1 fill (80 to $90 \mathrm{~cm}$ bs). This specimen is not burned, but is carnivore-gnawed. It compares favorably to turkey, but because of fragmentation, a specific identification was not possible.

\section{Class Mammalia}

Order Marsupialia, Family Didelphidae: Opossum (Didelphis marsupialis) is represented by three charred cranial fragments. They were recovered from Level 7 in Feature 1 fill, 60 to $70 \mathrm{~cm}$ bs.

The opossum is the only marsupial in North America, and is among the most primitive of living mammals. It can be found in woodlands and along streams throughout most of the eastern half of the country, south into Mexico, and along the Pacific coast. Sometimes it is hunted for sport, especially in the South, but the edible meat is oily. Occasionally it is blamed for poultry raids, but also consumes many mice and insects. The fur is salable, but of little value (Burt 1980).

Order Lagomorpha, Family Leporidae: Cottontail rabbit (Silvilagus sp.) is represented by a single specimen. This burned ulna fragment was recovered from Level 13 in Feature 1 fill (130 to $140 \mathrm{~cm}$ bs). Currently, two species of cottontail inhabit the area: the Eastern cottontail (S. floridanus) prefers heavy brush, strips of forest with open areas, edges of swamps, and weed patches; swamp rabbit (S.aquaticus) prefers swamps, marshes, and wet bottomlands (Burt 1980). Osteologically, the swamp rabbit is the largest of the cottontails within its range (Davis 1978). Based on fragmentary remains, the size of this specimen compares more favorably to the smaller Eastern cottontail.

Order Rodentia, Family Sciuridae: Squirrel (Sciurus sp.) is represented by a femur shaft fragment recovered from Level 6 in the midden deposit $(50$ to $60 \mathrm{~cm} \mathrm{bs})$. The specimen is not burned. Currently, two species are found in the area. The Eastern fox squirrel (S. niger) prefers pine forests with interspersed clearings in the south, and the Eastern gray squirrel (S. carolinensis) prefers hardwood forests with nut trees and river bottoms (Burt 1980).

Order Artiodactyla: Medium artiodactyl is represented by 32 specimens. They were recovered from 10 different levels. Quantities from each level range from one to four, except for the 13 fragments from Level 14 in the fill of Feature 1 (140 to $150 \mathrm{~cm}$ bs). Twenty-nine specimens are burned. These are most likely the remains of white-tailed deer (Odocoileus virginianus). This is the only species that is found in forests, swamps, and open brushy areas nearby (Burt 1980). Prehistorically, other species may have been present, but the elements found in this site assemblage are from smaller individuals. Whitetail deer are known for their small size, as compared to the larger mule deer of the western United States. At least one individual was present at the site.

Medium artiodactyl (deer) is probably also represented in the unidentifiable large mammal category $(n=334)$. Large mammal bones were recovered from all levels. Totals range from two to 78 , and most of these fragments are burned $(n=301)$. Again, the majority of these remains came from Level 14 in Feature 1 fill (140 to $150 \mathrm{~cm} \mathrm{bs).}$ 
Family Cervidae is also represented by four burned antler fragments recovered from Levels 2, 5, and 8. These too are most likely deer remains rather than elk.

\section{Assemblage Condition}

The faunal sample from the Hardin A site is highly fragmented, explaining the low identifiability rate. Taphonomic patterns are absent on 490 specimens. Surface observations include root etching $(n=2)$ and exfoliation $(n=3)$. Eighty-seven percent of the site sample is burned $(n=432)$, and most of these pieces came from Level 14 in Feature 1 fill (140 to $150 \mathrm{~cm}$ bs). The burning is probably a result of trash disposal.

In addition to weathering, spiral fracturing was recorded during analysis. Spiral fractures are the result of impact, such as striking with a hammerstone or breaking on an anvil. It is a common, expedient technique used in tool manufacturing, bone processing, and refuse disposal. Usually associated with large mammal long bones, spiral fracturing can also occur during trampling, carnivore gnawing, or any other severe impacts not necessarily associated with human activity. Forty-three large mammal bones and three medium artiodactyl bones are spirally fractured. The remainder of the large mammal sample is angularly fractured, suggesting bone grease processing. The bones are broken into small pieces and boiled in water. The floating fat is then skimmed from the top of the pot. The substance is used for frying and other culinary purposes. This practice has been well documented over time, and is a method used by many different cultures (Leechman 1950).

Scavenging activities are minimal. Carnivore gnawing was observed on three specimens, and three pieces are rodent gnawed.

\section{Distribution}

The distribution of faunal remains within the midden deposit and Feature 1 fill in Unit 1 is presented according to context and level.

\section{Midden Deposit ( $n=145)$}

\section{Level 1 (0 to $10 \mathrm{~cm} \mathrm{bs)}$}

Four faunal specimens were recovered from the first level of Unit 1. The sample is comprised of one box turtle shell fragment, two large mammal long bone fragments, and a medium artiodactyl humerus fragment. These four pieces are burned, and two are spirally fractured.

Level 2 (10 to $20 \mathrm{~cm} \mathrm{bs)}$

Level 2 yielded 21 faunal specimens. The sample is dominated by large mammal remains, but includes indeterminate vertebrate and antler fragments. Seventeen pieces are burned, and one large mammal long bone fragment is spirally fractured.

Level 3 (20 to $30 \mathrm{~cm} \mathrm{bs)}$

Level 3 yielded 10 large mammal bone fragments, two pieces of unidentifiable turtle shell, and one gar vertebra. The gar bone and one large mammal bone are not burned, but the remaining 11 specimens are burned. Eight large mammal bones are spirally fractured. 
Level 4 (30 to $40 \mathrm{~cm} \mathrm{bs)}$

A total of 22 faunal specimens were recovered from Level 4. The sample consists of 18 large mammal bone fragments, three medium artiodactyl elements, and a small piece of unidentifiable turtle shell. Eighteen fragments are burned, and six of these pieces are spirally fractured. Slight cuts are visible on one large mammal rib fragment, indicative of butchering, and probably skinning.

Level 5 (40 to $50 \mathrm{~cm} \mathrm{bs)}$

Level 5 yielded a total of 30 faunal specimens, including 18 large mammal bone fragments. The remainder of the collection consists of four indeterminate vertebrate remains, three pieces of turtle shell, one turkey bone, two medium artiodactyl bones, and two antler fragments. Twenty-four fragments are burned, and two fragments are spirally fractured.

Level $6(50$ to $60 \mathrm{~cm} \mathrm{bs})$

A total of 55 faunal specimens were recovered from Level 6, the last level of the midden deposit. The sample is comprised of indeterminate vertebrate, unidentifiable medium fish, unidentifiable turtle shell, musk/mud turtle shell, unidentifiable mammal, large mammal, and squirrel. Forty five fragments are burned, including the 39 large mammal bones, four pieces of turtle shell, and the two musk/mud turtle shell fragments. Two large mammal bone fragments are spirally fractured.

\section{Feature 1 Fill (n=350)}

\section{Level 7 (60 to $70 \mathrm{~cm} \mathrm{bs)}$}

Thirteen faunal specimens were recovered from Level 7, the first level of Feature 1 fill. The collection from this level is composed of indeterminate vertebrate, unidentifiable medium fish, buffalo fish, turtle shell, large mammal, opossum, and rabbit remains. Ten specimens are burned, and one large mammal bone fragment is spirally fractured.

\section{Level 8 (70 to $80 \mathrm{~cm} \mathrm{bs)}$}

Level 8 yielded 44 faunal specimens, dominated by large mammal remains $(n=29)$. The remainder consists of indeterminate vertebrate, unidentifiable medium fish, unidentifiable turtle shell, musk/mud turtle shell, medium artiodactyl, and antler fragments. Twenty-seven pieces are burned, including 20 of the large mammal bones, two of the medium artiodactyl bones, and the antler and turtle shell fragments. Twelve of the large mammal bones are spirally fractured.

Level 9 (80 to $90 \mathrm{~cm} \mathrm{bs)}$

Fifteen faunal specimens were recovered from Level 9, consisting of unidentifiable medium fish, gar, unidentifiable turtle, unidentifiable large bird, large mammal, and medium artiodactyl remains. Five of the large mammal bones, the gar bone, and the turtle shell fragment are burned. Seven large mammal bones and the medium artiodactyl bone are spirally fractured. 
Level 10 (90 to $100 \mathrm{~cm} \mathrm{bs)}$

Level 10 had only nine faunal specimens: two indeterminate vertebrate bones, six large mammal bones, and one piece of unidentifiable turtle shell. All fragments are burned, except for two large mammal bones. One of the large mammal bones is spirally fractured.

\section{Level 11 (100 to $110 \mathrm{~cm} \mathrm{bs})$}

Level 11 yielded 21 faunal specimens, including 11 large mammal and three medium artiodactyl bones. The remainder of the sample consists of indeterminate vertebrate and unidentifiable turtle shell. Sixteen fragments are burned, and three fragments are spirally fractured.

\section{Level $12(110$ to $130 \mathrm{~cm} \mathrm{bs})$}

A total of 55 faunal specimens were collected from this level, including five unidentifiable small mammal bones and three unidentifiable turtle shell fragments. The remainder of the sample is comprised of 43 large mammal bones and four medium artiodactyl bones. Fifty two specimens are burned.

\section{Level 13 (130 to $140 \mathrm{~cm} \mathrm{bs)}$}

Forty faunal specimens were recovered from Level 13. The sample is dominated by large mammal remains $(n=31)$, but also includes unidentifiable turtle shell, small mammal, cottontail, and medium artiodactyl. The entire level collection is burned.

\section{Level 14 (140 to $150 \mathrm{~cm} \mathrm{bs})$}

Level 14 yielded 120 faunal specimens, 24\% of the entire Hardin A site assemblage. This is by far the highest recovery of all levels. Again, large mammal remains dominate the sample $(n=78)$. The remainder of the collection consists of indeterminate vertebrate $(n=16)$, unidentifiable turtle shell $(n=6)$, small mammal $(n=7)$, and medium artiodactyl $(n=13)$. All of the bone fragments from this level are burned.

\section{Level 15 (150 to $160 \mathrm{~cm} \mathrm{bs)}$}

Thirty-three faunal specimens were recovered from this final level of Unit 1 . As with the other levels, large mammal is the most abundant $(\mathrm{n}=17)$. Turtle shell fragments and medium artiodactyl are also recorded. The remaining 12 bone fragments are unidentifiable. Again, all of the bones from this level are burned.

\section{SUMMARY}

A total of 145 faunal specimens were recovered from Levels 1 through 6 in the midden deposit of Unit 1 (0 to $60 \mathrm{~cm}$ bs), $29 \%$ of the Hardin A site faunal sample. Identified taxa is comprised of fish, turtles (including the only box turtle shell fragment), turkey, squirrel, and deer: 120 pieces are burned.

The fill of Feature 1, a large, probable storage feature filled with trash, yielded a combined total of 350 faunal specimens from Levels 7 through 15 in Unit 1 (60 to $160 \mathrm{~cm} \mathrm{bs}$ ). Taxa identified is similar to that of the midden deposit (fish, turtles, large bird, and deer), but also includes the remains of unidentifiable small mammal, opossum, and cottontail; 312 pieces are burned. 
Taxonomic composition of the Hardin A fauna is typical of ancestral East Texas Caddo faunal assemblages. The collection suggests a dietary reliance on large game animals such as deer, supplemented by fish, turtle, large bird/turkey, and smaller mammals such as opossum, rabbits, and squirrel. Undoubtedly the occupants of the site utilized the rich resources of East Texas to supplement their diet, and the presence of opossum may indicate the utilization of fur-bearing mammals for skins.

\section{REFERENCES CITED}

Behler, J. L.

1995 National Audubon Society Field Guide to North American Reptiles and Amphibians. Chanticleer Press, New York.

Boyd, B. E. and T. K. Perttula

2001 Initial Findings from the Archeological Investigations of the Hardin A Site (41GG69), Gregg County, Texas. Caddoan Archeology 12(1):5-10.

Burt, W. H. and R. P. Grossenheider

1980 A Field Guide to the Mammals. 3rd edition. Houghton Mifflin Co., Boston.

Collins, H. H., Jr.

1959 Complete Field Guide to American Wildlife. Murray Printing Co., Forge Village, Massachusetts.

Conant, R.

1975 A Field Guide to Reptiles and Amphibians of Eastern and Central North America. 2nd edition. Houghton Mifflin Co., Boston.

Davis, W. B.

1978 The Mammals of Texas. Bulletin No. 41, revised. Texas Parks and Wildlife Department, Austin.

Gilbert, B. M.

1980 Mammalian Osteology. B. M. Gilbert, Publisher, Laramie.

Leechman, D.

1951 Bone Grease. American Antiquity 16(4):355-356.

Munzel, S.

1986 Quantitative Analysis and the Reconstruction of Site Patterning. Paper presented at the Vth International Conference of the International Council for ArchaeoZoology, Aug. 25-30, Bordeaux.

Newcomb, W.W., Jr.

1993 The Indians of Texas. University of Texas Press, Austin.

Olsen, S.J.

1964 Mammal Remains from Archaeological Sites, Part I: Southeastern and Southwestern United States. Papers, Vol. 56(1). Peabody Museum of Archaeology and Ethnology, Harvard University, Cambridge.

Robbins, C. S., B. Bruun, and H. S. Zim.

1983 A Guide to Field Identification: Birds of North America. Western Publishing, Racine, Wisconsin.

Schmid, E.

1972 Atlas of Animal Bones. Elsevier Publishing, Amsterdam. 